\title{
PEMBUATAN PAPAN INFORMASI
}

\author{
NURMEILANI
}

9173770410300

nurmeilaniiiii@gmail.com

1. Bentuk Kegiatan

$>$ Pembuatan papan informasi

2. Lokasi

$>$ Rumah masyarakat desa Bontocini.

3. Hari/Tanggal dan Waktu

$>$ Hari jum'at 15 oktober - 19 oktober. Pukul 18:30 - selesai.

4. Peserta yang Dilibatkan

> Mahasiswa KKLP Yapti Jeneponto

$>$ Karang Taruna desa Bontocini

5. Alasan diadakannya

> Alasan diadakannya pembuatan papan informasi ini adalah karena mengingat pentingnya suatu informasi ini maka kami membuatkan papan informasi bagi tiap-tiap pos ronda di desa Bontocini.

6. Tujuan dan Manfaat

$>$ Tujuan dan manfaatnya yaitu untuk mempermudah penyebaran informasi kepada masyarakat desa Bontocini sehingga tidak perlu lagi mengunjungi rumah masyarakat satu persatu.

7. Produk yang dihasilkan

$>4$ buah papan informasi.

8. Deskripsi Kegiatan

$>$ Kegiatan pembuatan papan informasi ini berjalan lancar. Kami menyebarkan papan informasi ini di 4 pos ronda di 4 dusun. Pemasangan papan informasi ini dilakukan pada tanggal 19 oktober 2020. Kami membuat papan informasi ini dari bahan tripleks karena ketersediaan dana yang terbatas. 
